\title{
Educational intervention for the prevention of diarrheal diseases in the Mano de Dios neighborhood, Sincelejo, Colombia: A success experience
}

\author{
Gloria Villareal, Nurse ${ }^{1}$, laura Álvarez, Nurse ${ }^{2}$, Katherine Jiménez, Nurse ${ }^{3}$, \\ Karina Martínez, Nurse ${ }^{4}$, Etilvia Martínez, Nurse ${ }^{5}$, Carolina OJeda, Nurse $^{6}$
}

\section{SUMMARY}

Objective: To measure the effectiveness of an educational program, that encourages the adoption of healthy behaviors in caregivers, to prevent diarrheal diseases in children under five years of age.

Design: Quasi experimental educational intervention (before-after type), adopting the interrupted time series design with a group (Burns and Grove 2008) and the Health Beliefs theory of Hochbaum.

Materials and methods: We repeatedly measured the effect of an educational program to promote the adoption of healthy behaviors toward the prevention of acute diarrheal disease in 17 caregivers of children under 5 years of age in a marginal suburb of the city of Sincelejo (Colombia). A standardized questionnaire and a semi-structured interview was applied on two occasions (before and after) to investigate the beliefs about the perception of severity and identification of risk factors and prevention of disease, an observation guide to follow changes in beliefs was also used.

Results: We found a low presence of healthy beliefs in all dimensions before the implementation of the program and a high proportion of variation of change after the intervention, except in the perception of benefits, which turned out to be the same before and after the intervention. The greatest predictor of change was the perception of the severity of the disease, with a coefficient of variation of $100 \%$.

Conclusions: The effectiveness of an educational program to adhere to an expected behavior is achieved by using the synergy of educational and communication elements in health behavior theories that go beyond the cognitive to the affective and structure of volition.

Keywords: Health promotion; Health education; Health behavior; Health communication.

Colomb Med. 2011; 42: 319-26

Intervención educativa para la prevención de enfermedades diarreicas en el barrio Mano de Dios, Sincelejo, Colombia: Una experiencia exitosa

\section{RESUMEN}

Objetivo: Medir la efectividad de un programa educativo que favorezca la adopción de conductas saludables en cuidadores, para prevenir las enfermedades diarreicas agudas (EDA) en menores de 5 años.

Diseño: Intervención educativa cuasi experimental de tipo antes y después, siguiendo el diseño de serie temporal interrumpida con un grupo (Burns y Grove 2008) y la Teoría de las Creencias de la Salud de Hochbaum.

Materiales y métodos: Se midió en forma repetida, el efecto de un programa educativo para promover la adopción de conductas saludables hacia la prevención de la EDA en 17 cuidadores de menores de 5 años, en un barrio con marginalidad de la ciudad de Sincelejo, Colombia. Se aplicó una encuesta estandarizada y una entrevista semi-estructurada en los dos momentos (antes y después), para indagar las creencias, acerca de la percepción de gravedad e identificación de factores de

1. Professor, Department of Nursing, Faculty of Health Sciences, Sincelejo, Colombia. e-mail: gvamaris@hotmail.com

2. Professor, Practice Supervisor, Centro de Estudios de la Costa (CECOM), Sincelejo, Colombia. e-mail: lauritaalvarez1206@hotmail.com

3. Nurse, Hospital Universitario de Sincelejo, Chief Adult ICU, Sincelejo, Colombia. e-mail: kjimeneza@hotmail.com

4. Nurse, ESE Hospital Santiago de Tolú, Epidemiological Surveillance, Tolú, Colombia. e-mail: anirak50530@hotmail.com

5. Professor, Instituto Educativo Técnico (INETEC), Chinú, Colombia. e-mail: etilvia0210@hotmail.com

6. Nurse, Associate Neonate ICU, Chief Associate Neonate ICU, Magangué, Colombia. e-mail: karito.0315@hotmail.com Received for publication December 6, 2010

Accepted for publication May 17, 2011 
riesgos y prevención de la enfermedad y una guía de observación para monitorear el cambio en las creencias.

Resultados: Se encontró una baja presencia de creencias saludables en todas las dimensiones antes de la intervención y una alta proporción de variación de cambio después de la intervención, excepto en la percepción de beneficios que fue igual, tanto en el antes como en el después de la intervención. La mayor predicción de cambio fue la percepción de la gravedad de la enfermedad, con un coeficiente de variación del $100 \%$.

Conclusiones: La efectividad de un programa educativo para la adherencia a una conducta esperada se logra con la sinergia de utilizar la educación y la comunicación en salud con las teorías del comportamiento que trascienda lo cognitivo hacia lo afectivo y lo volitivo.

Palabras claves: Educación en salud; Promoción de la salud; Conducta en salud; Comunicación en salud.

Colomb Med. 2011; 42: 319-26

Acute diarrheal disease is considered a public health problem because it is still one of the most frequent causes of morbidity in children under five years of age, affecting their growth and development ${ }^{1}$. It expresses with greater evidence, than other pathologies, the poor conditions in quality of life of the population; hence, the probability of getting sick or dying due to diarrhea is directly related to individual and family life styles, hygienic and environmental conditions in which people live.

The World Health Organization's (WHO) goal, as with the objectives of the millennium, is to reduce morbidity due to this cause. In this sense, it promotes primary attention policies and strategies to draw nearer healthcare services and promote collective health. Health education is highlighted among the key measures to prevent diarrheal disease.

The WHO defines Health education as «an educational activity designed to expand the knowledge of the population regarding health and develop the personal values and skills that promote health $\rangle^{2}$.

The Colombian Social and Health Security System, through its Public Healthcare Attention Plan, grants health education activities a leading role in the search to broaden the population's knowledge regarding health to, thus, promote behavioral changes and generate healthy behaviors ${ }^{3}$. These activities are carried out for the purpose of encouraging practices and promoting health prevention conducts, without them, not having reached changes in their expected behaviors and beliefs, especially to eliminate the risk factors precursors of acute diarrheal diseases (ADD).

From the operational and technical points of view, health promotion and education has been reduced to a series of «talks» in institutions or in other locations, which are set up to offer collective health education actions, and are centered on repetitive information. Consequently, educational interventions are homogenized without exploring the community's prior information; their beliefs, interpretations, and practices regarding health, disease, and self-care ${ }^{4}$. Also, changes of beliefs and values are promoted on certain harmful behaviors, emphasizing on the negative repercussions of not putting them into practice.

Health education, as an essential strategy in health promotion, has learning as an objective. To achieve significant learning with individuals or groups in the community, the traditional approaches or orientations are not sufficient or efficient, given that they use advices as methodology; thereby, what is required are active, communicative, and participative pedagogical strategies, more than merely interrogative strategies. Hence, educating is more than merely informing ${ }^{5}$.

Factors like the consumption of contaminated foods outside of the home, deficiencies in the elimination of solid wastes and excreta, inappropriate practices of personal hygiene, and early weaning are clearly associated to life styles and environmental factors ${ }^{6}$. This has led to growing interest toward health promotion and education as a strategy to address life style modifications because these determine the responses or behaviors of individuals.

Behavior plays an important role on the incidence, prevalence, and sequelae of diarrhea during childhood, because of this; behavioral changes and acquisition of adequate practices will have a significant impact on childhood health. The impact of the interventions could be estimated with low-cost methodologies and less complexity ${ }^{7}$.

In consequence, upon undertaking health education actions, healthcare personnel cannot neglect the value of the cognitive factor as determinant or predisposing of behavioral changes and the adoption of healthy life styles. Awareness of something, per se, is not an indicator of behavioral change, although it has been demonstrated that a certain amount of information is necessary to start 
the process that would lead to behavior changes ${ }^{8}$.

Any preventive intervention must start from a theoretical model, which must derive from observation, proof, and elaboration of a conceptual framework that permits understanding that part of reality upon which that theory was formulated.

Considering the scarcity of the theoretical reference on intervention models, it is important for healthcare personnel to solve the query of adequate design of healthcare prevention and intervention models with certain population groups, which include cognitive factors that produce the desired impact, or at least, increase probabilities for success. Because of this, cognitive, social, and behavioral theories supply valuable elements that provide a structure to support the planning, execution, and evaluation of said models ${ }^{8}$.

One of the models most used in health promotion is the theory of Health Beliefs by Hochbaum, Rosenstock.

This model addresses the perceptions an individual has of the threat of a health problem, along with the evaluation of a recommended behavior to prevent or manage a problem. Said model is useful to analyze the lack of action or individual non-compliance, identifying the reasons for such. The health beliefs model has a good fit when the behavior or the affection constituting a problem raise health motivation, given that it is precisely the central issue or starting point of the whole intervention process 9 .

Bearing in mind that in Colombia intervention studies are scarce in health education on the prevention of acute diarrheal disease, founded on health prevention and intervention models, an educational intervention program was designed in light of the theory of health beliefs.

The purpose of the study was to measure the effectiveness of the educational program in caregivers of children under five years of age in the Mano de Dios neighborhood of the city of Sincelejo, Colombia, concentrating its actions on the beliefs and risk factors most frequently associated to diarrheas and, thus, contributing to the awareness of new methodologies to approach health education processes, which promote behavioral changes and adoption of healthy behaviors.

\section{MATERIALS AND METHODS}

A before and after quasi experimental educational intervention study was conducted; following the interrupted time series design with a group (Burns and Grove 2008) ${ }^{10}$, which was measured repeatedly, both before and after the application of the educational program designed in light of Hochbaum's theory of health beliefs.

The work was approached methodologically in stages: the first conducted the documentation and the theoretical reflection for the conceptual construction of the methodological proposal based on the theory of health beliefs by Hochbaum. The second made calls through the 28 community homes for the caregivers of children under five years of age to select those whose children had presented episodes of diarrhea within the past year. Motivation workshops were delivered for participation in the study; leading to the conformation of the work group, and the informed consent form was filled out. A (prior) reference diagnostic assessment was made of the knowledge and beliefs on the perception of the gravity and the susceptibility of the disease and on the need to apply preventive measures, whose information served as foundation in the design of the educational program.

The third stage put into practice the methodological proposal with the application of the educational program, comprising eight workshops designed with participative, demonstrative, and communicative educational strategies focusing on weaknesses detected during the initial evaluation, which served to motivate the participants and measure progress in the construction of their process of change.

The group of researchers and participants sealed the work commitment by wearing a t-shirt with the logo of the working conduct, «Together we will have children without diarrhea». This was done to identify and market the expected behavior, besides motivating participation and permanence in the project.

A fourth stage monitored and followed up the measurable and exteriorized target changes by the participants at three and six months after applying the educational program. During this same stage, the participants of the project reported what they had learnt to members of the community during a health fair denominated «Lets avoid diarrhea in children» and through a radio program through the broadcast station at Universidad de Sucre (UniSucre FM estereo) where they commented on their experiences and the learning process. 
The study had a target population of 392 mothers or caregivers of children under five years of age, who were part of the 28 community homes from the Mano de Dios neighborhood, selected because they were located in the Social Projection area of influence of the Faculty of Health Sciences. The sampling framework applied the inclusion criterion of mothers or caregivers of children under five years of age who in the past year had had at least one episode of acute diarrhea, obtaining a sample of 57 mothers or caregivers.

For the sample size, the Cultural Consensus Model by Romney and Batcheldery, Weller was kept under consideration $^{11}$. This model states that, in cultural description studies, the size of the sample should not be big, because the mean correlation among informants tends to be high ( 0.5 or more). In this sense, Romney suggests a minimum of 17 informants to correctly classify $95 \%$ of the questions and the estimated pattern of correct responses from the group of 0.5 and confidence level of 0.95 .

After the call and motivation activity, 20 caregivers agreed to participate with whom the educational program was begun upon signing the informed consent form. Active participation was secured from 17 caregivers who attended all the programmed activities and there were three caregivers with irregular participation, which is why their data are not part of the results.

The sample total was 17 women, ranging in ages between 18 and 59 years; $76.4 \%$ were affiliated to the subsidized healthcare regime, $94.1 \%$ had some degree of schooling, ranging from grade school to technical level and; $52.9 \%$ had inadequate hygienic and environmental conditions in the homes.

A standardized questionnaire was used consisting of the following sections: socio-demographic data: age, gender, affiliation to healthcare, level of schooling, hygienic conditions in the homes, and data on the dimensions of the main independent variables related to the intention of changing beliefs: beliefs on the perception of the severity of the acute diarrheal disease, beliefs or perception of the susceptibility to the disease, beliefs they have on the benefit of applying preventive measures, and beliefs on the consequences generated on children under five years of age by applying or not applying preventive measures.

A semi-structured interview was conducted with six questions designed to explore levels of caregiver knowledge of the disease, risk factors and measures to prevent ADD. Additionally, an observation guide was used through which follow up was made of the protective measures that made up the reference expected behavior to systematically determine changes in the unhealthy beliefs detected during the initial evaluation.

To evaluate the variable on the beliefs on the seriousness of the disease, 13 questions were applied related to their beliefs on the seriousness of the diarrheal disease; they were asked to indicate among the 13 items those they considered important or that placed them in danger of contracting the disease. Responses were grouped into two categories: adequate and inadequate. Zero points were assigned for inadequate or unhealthy beliefs and 1 point for adequate or healthy beliefs; a total score between 13 and 7 points being adequate or healthy and from 6 to 0 points being inadequate or not healthy.

The evaluation of the variable on beliefs on the susceptibility to ADD, 13 questions were designed on whether their habits or behaviors present a risk or not to children under five years of age to develop the diarrheal disease. Their responses were classified as adequate and inadequate. A score of 0 was assigned if the child was placed at risk and 1 point if the child was not placed at risk; for a final classification of adequate or healthy between 13 and 7 points and inadequate or unhealthy between 6 and 0 points.

For the variable on beliefs on the benefit of applying measures to prevent ADD, 13 questions were also applied related to beliefs on the benefit of applying the preventive measures. They were grouped into two response categories: adequate and inadequate, assigning a score of 1 point for beliefs referring to obtaining benefits and 0 points for beliefs related to not obtaining benefits. These were scored adequate between 13 and 7 points and inadequate between 6 and 0 points.

Beliefs on the consequences of the disease on children under five years of age were also evaluated with 13 questions related to the beliefs on the consequences generated on the children by applying or not applying preventive measures. Two categories were conformed with the responses: adequate and inadequate. Adequate responses were assigned 1 point and a score of 0 was for the category of inadequate responses.

The instruments were subjected to a pilot test in a population similar to that selected, which permitted 
identifying weaknesses in their application, as well as inadequate or confusing formulation of questions, and the respective corrections were made. Application of the instruments, both for the initial and final evaluations, was executed by the group of researchers, working in four two-hour sessions with collective and individual work, one per dimension to generate the motivational climax.

Tabulation of the information was done via a Microsoft Excel 2007 spreadsheet. A frequency analysis was made for each of the variables. Processing was performed via the SPSS statistical package for Windows version 11.5. The coefficient of variation $(\mathrm{CV})$ was calculated to see the percentage of change of the results after the intervention, which was obtained through the following expression:

$$
C V=\frac{\text { Initial value }- \text { Final value }}{\text { Initial value }} \times 100
$$

Where:

Initial value: Total number of participants with inadequate beliefs prior to the intervention.

Final value: Total number of participants with inadequate beliefs after the intervention.

To determine the behavioral changes and, consequently, the effectiveness of the educational program, we used the McNemar test with a significance level of alpha $=0.05$.

Ethical aspects. The research was conducted by addressing the criteria in Resolution $\mathrm{N}^{\circ} 8430$ of 1993 with approval from the Institutional Ethics Committee. The participants received information about the objective of the study, respect, reliability, and privacy of the data gathered; they were also given the liberty to withdraw from the study when they so decided. Additionally, an informed consent was obtained from them.

\section{RESULTS}

Among the caregivers of children under five years of age (17), 35.3\% ranged between 18 and 24 years of age; $76.4 \%$ were affiliated to the subsidized healthcare regime; $94.1 \%$ had some level of schooling, which goes from grade school to the technical level.

Regarding the hygienic and environmental conditions
Table 1

Distribution of caregivers according to knowledge of acute diarrheal disease before and after the intervention

\begin{tabular}{lcccrc}
\hline Knowledge & \multicolumn{2}{c}{ Before } & \multicolumn{2}{c}{ After } & \multicolumn{2}{c}{ Coefficient of } \\
& $\mathbf{N}^{\circ}$ & $\%$ & $\mathbf{N}^{\circ}$ & $\%$ & variation \\
\hline Adequate & 8 & 47 & 16 & 94.1 & $88.9 \%$ \\
Inadequate & 9 & 53 & 1 & 5.9 & \\
\hline
\end{tabular}

in the homes, $52.9 \%$ were inadequate, $100 \%$ had good lighting and ventilation, $17.7 \%$ were overcrowded, $82.3 \%$ had running water, $17.7 \%$ purchased water, and $100 \%$ had a sewage system.

A total of $23 \%$ of the caregivers included in the study reported at least one diarrhea episode among children under five years of age within the past three months.

At the beginning of the educational intervention, inadequate knowledge predominated on the acute diarrheal disease; however, this was inverted by the end of such intervention, obtaining a significant modification of adequate knowledge (increase of $88.9 \%$ ) with respect to the initial moment (Table 1).

The aspects in which the caregivers presented greater change in relation to the initial evaluation, the concept of acute diarrheal disease at $52.9 \%$ was represented by 9 caregivers, risk factors for the disease at $47.1 \%$ was represented by 8 caregivers, and the consequences at $41.2 \%$ was presented by 7 caregivers.

Inadequate responses on the beliefs related to the perception of the severity of the disease were predominantly adequate during the initial evaluation, with the intervention the percentage of the adequate practices and responses was raised significantly at the end of such (100\%) (Table 2).

The specific beliefs with less identification like risk factor were: wash fruits and vegetables with cool boiled water $88.3 \%$ (15), breastfeed children under two years of age during the disease and up to six months of age $64.7 \%$ (11), wash hands with soap and water and keep the latrine or toilet clean and frequently use toilet paper $52.9 \%$, boil milk and water for consumption $47.1 \%(8)$, among others. These beliefs were modified after the intervention when increasing the adequate practices and responses, with these being the main predictors of 
change; therein, provoking an increase of caregivers with a good concept referring to the risk factors for diarrheal diseases.

Prior to the intervention, the inadequate responses on whether to apply or not apply preventive measures making children vulnerable to acute diarrheal disease were higher than the adequate responses. After the intervention, there was an important increase in the order of $77.8 \%$, and in $11.7 \%$ their responses were inadequate before and after the educational intervention (Table 3).

In the initial evaluation, the preventive measures with the least consideration were: complying with the current immunization schedule, at $100 \%$ according to the child's age, storing food in sealed containers at $94.1 \%$, avoiding trash near/around the home $82.3 \%$, maintaining trash uncovered and proliferation of flies in the house and keeping a clean kitchen at $70.5 \%$, respectively, washing hands with soap and water and collecting trash in a covered container and proper disposal of said trash at $58.8 \%$, respectively, and measures of boiling milk and water prior to consumption, washing fruits and vegetables with cool boiled water, keeping the latrine and toilet clean, breastfeeding children under two years of age during acute diarrheal disease and exclusively until six months of age at $52.9 \%$, respectively.

These considerations were modified after the intervention, reaching a high level of responses about the perception of risk of ADD, with high participation in the proportion of change of the beliefs of caregivers. Only two caregivers did not modify their perception on risk.

On the perception on the benefits of applying preventive measures on ADD, both during the initial evaluation as in the final assessment, $100 \%$ (17) of their considerations were positive or healthy. Among the responses, we can cite: does not get sick 58.8\% (10), adequate growth and development $23.5 \%$ (4), does not know/no response $11.7 \%$ (2), and avoids hospitalization and does not get sick 5.9\% (1).

Regarding the perception of beliefs on the consequences of applying or not preventive measures for acute diarrheal disease, during the initial moment we found a higher incidence of inadequate responses than adequate responses. With the intervention, the percentage of adequate responses increased, only one
Table 2

Distribution of caregivers according to beliefs on the gravity of the disease before and after the intervention

\begin{tabular}{|c|c|c|c|c|c|c|}
\hline \multirow{2}{*}{$\begin{array}{l}\text { Gravity of } \\
\text { the disease }\end{array}$} & \multicolumn{3}{|c|}{ Before } & \multicolumn{2}{|c|}{ After } & \multirow{2}{*}{$\begin{array}{l}\text { Coefficient } \\
\text { of variation }\end{array}$} \\
\hline & $\mathbf{N}^{\circ}$ & & $\%$ & $\mathbf{N}^{\circ}$ & $\%$ & \\
\hline \multirow{2}{*}{$\begin{array}{l}\text { Adequate } \\
\text { Inadequate }\end{array}$} & 6 & & 35 & 17 & 100 & \multirow{2}{*}{$100 \%$} \\
\hline & 11 & & 5 - & - & - & \\
\hline \multicolumn{7}{|c|}{$\begin{array}{c}\text { Table } 3 \\
\text { Distribution of caregivers according to } \\
\text { perception on the susceptibility of ADD before } \\
\text { and after the intervention }\end{array}$} \\
\hline \multirow{2}{*}{\multicolumn{2}{|c|}{ Susceptibility }} & \multicolumn{2}{|c|}{ Before } & \multicolumn{2}{|c|}{ After } & \multirow{2}{*}{$\begin{array}{l}\text { Coefficient } \\
\text { of variation }\end{array}$} \\
\hline & & $\mathbf{N}^{\circ}$ & $\%$ & $\mathbf{N}^{\circ}$ & $\%$ & \\
\hline Adequate & & 8 & 47 & 15 & 88.3 & $77.8 \%$ \\
\hline Inadequate & & 9 & 53 & 2 & 11.7 & \\
\hline
\end{tabular}

caregiver did not improve the incidence of inadequate responses (Table 4).

Prior to the intervention, the observation registered inadequate habits and practices by $53 \%(9)$ and adequate habits and practices by $47 \%(8)$. After the intervention, significant changes were registered by $88.3 \%$, upon increasing the adequate habits and practices and predominating over the inadequate habits and practices initially noted, obtaining a coefficient of variation of $77.8 \%$ (Table 5).

During and after the intervention, changes were progressively noted in all the dimensions of the beliefs subjected to being studied. The most evident changes were in the beliefs on the severity of the acute diarrheal disease at $100 \%$ and in the consequences of not applying preventive measures at $88.9 \%$, which had the greatest participation in change. The beliefs on the benefits of applying or not preventive measures had the least participation.

Through a check list, applied before, during and after the intervention, progressive changes were noted in some of the specific conducts from all the dimensions of the beliefs subjected to be studied, like: knowledge/ awareness, habits, and practices, perception of susceptibility, and especially the perception of the gravity of 
Table 4

Distribution of caregivers according to perception on the consequences of applying or not preventive measures before and after the intervention

\begin{tabular}{lrrrrr}
\hline Consequences & \multicolumn{2}{c}{ Before } & \multicolumn{2}{c}{ After } & Coefficient \\
& $\mathbf{N}^{\circ}$ & $\%$ & $\mathbf{N}^{\circ}$ & $\%$ & of variation \\
\hline Adequate & 6 & 35 & 16 & 94.1 & $88.9 \%$ \\
Inadequate & 11 & 65 & 1 & 5.9 & \\
\hline
\end{tabular}

the consequences. These changes are confirmed through the McNemar test inasmuch as the null hypothesis is rejected, which states: "That the beliefs were equal before and after the intervention» because the results were different (Table 6).

Although monitoring the incidence of acute diarrhea disease was not a motive of the investigation, during the months prior to the application of the program, the time during which it took place, and the three months after its application there were no episodes of diarrhea.

\section{DISCUSSION}

The objective of the study referred to measuring the effect of the educational program; in this regard, the educational intervention achieved important changes in the beliefs of the caregivers of children under five years of age, with beliefs on the severity of the disease, perception of the consequences, and awareness being those that more strongly predict it and less strongly benefit it. However, although the predictive value of the
Table 5

Distribution of caregivers according to habits and practices before and after the intervention*

\begin{tabular}{|c|c|c|c|c|c|}
\hline \multirow{2}{*}{$\begin{array}{l}\text { Habits and } \\
\text { practices }\end{array}$} & \multicolumn{2}{|c|}{ Before } & \multicolumn{2}{|c|}{ After } & \multirow{2}{*}{$\begin{array}{l}\text { Coefficient } \\
\text { of variation }\end{array}$} \\
\hline & $\mathbf{N}^{\circ}$ & $\%$ & $\mathbf{N}^{\circ}$ & $\%$ & \\
\hline Inadequate & 9 & 53 & 2 & 11.7 & \multirow{2}{*}{$77.8 \%$} \\
\hline Adequate & 8 & 47 & 15 & 88.3 & \\
\hline
\end{tabular}

* Observation Guide

beliefs on benefits of applying preventive measures was lower, it should not be neglected as unimportant upon applying educational programs with a tendency for behavioral changes.

Including the evaluation of the level of knowledge in the educational program is important because starting from the level of knowledge and reinforcing it through the educational process, enhances said level of knowledge and stirs interest toward change, as demonstrated in the study when knowledge resulted as one of the predictors of change in beliefs and of the effectiveness of the program. These results are similar to those found by Gutiérrez Camacho $2003^{12}$, who revealed that systematic training achieves improved knowledge by $60 \%$.

Another important finding was that the caregivers who raised their level of awareness also manifested such as a practice; results different from those reported by Ávila Montes et al., in their study ${ }^{13}$, concluding that knowing does not mean doing. These coincide with those found by Herrera et al. ${ }^{14}$ who carried out training to diminish the presence of ADD whose intervention

Table 6

Proportion of change per dimension of beliefs before and after the educational intervention, according to the McNemar test

\begin{tabular}{lcclc}
\hline Variable & Value calculated & Value tabulated & Conclusion & Definition \\
\hline Knowledge & 2.6 & 1.96 & Rejects Ho & Different \\
Habits and beliefs & 2.6 & 1.96 & Rejects Ho & Different \\
Perception of gravity & 3.0 & 1.96 & Rejects Ho & Different \\
Perception of susceptibility & 2.6 & 1.96 & Rejects Ho & Different \\
Benefit & - & 1.96 & Accepts Ho & Equal \\
Consequences & 3.0 & 1.96 & Rejects Ho & Different \\
\hline
\end{tabular}


achieved favorable behavioral changes in mothers of children under one year of age, raising the education level of the mothers.

From the approach of the educational program in light of the theory of health beliefs, it is important to clarify that different levels were accomplished of proportional change of beliefs on the gravity and susceptibility of the disease and the consequences of applying preventive measures, which through follow up and control permitted corroborating that these changes turned into actions. These results are different to those found by Páez Rovira et al. ${ }^{15}$, who found that neither the gravity, nor the susceptibility, or risk are associated with the preventive behavior; coinciding with other research on the application of theories of health beliefs, which state that diseases are a consequence of inadequate behaviors and that the conduct to prevent a disease is initiated if individuals perceive themselves susceptible to it and perceive the disease as an important issue (susceptible and severe) ${ }^{14}$.

Regarding the theory of health beliefs, it may be concluded that it is an efficient tool to work collective processes, as a main strategy of change stemming from an educational process, given that it is an excellent guide to permanently assess progress in the awareness of the reality being studied, as well as to motivate participants to find their own benefits by reducing the risk factors and lead them to adhering to the expected behavior. The behavior to prevent a disease is achieved if individuals perceive themselves susceptible to such and perceive the disease as a matter of importance (susceptible and severe) ${ }^{16}$.

The accomplishment of significant learning and behavioral changes depends upon the varied use of active, communicative, and participative pedagogical techniques, centering on their beliefs and the perception of their susceptibility to the disease.

Research conducted by the line of Community Health Research, Universidad de Sucre.

Conflict of interest. The authors declare having no conflict of interest within the group or with our Institutions.

\section{REFERENCES}

1. Jaramillo E, Estrada S, Ospina S. Etiología de la enfermedad diarreica aguda (EDA) de origen bacteriano, utilizando un protocolo estandarizado de laboratorio. Infectio. 1999; 3: 95-9.
2. Pérez MJ, Echauri M. Educación en salud en la adolescencia [Monografía en Internet]. Libro Congreso Adolescente. p. 6678. Pamplona: Instituto de Salud Pública de Navarra; 2002 [fecha de consulta: 29 de mayo de 2009]. Disponible en: http:/ /adolescenciasema.org/ficheros/CongresoPamplona/_ PAMPLONA Taller_EpS.pdf

3. Dirección de Salud de Antioquia. Plan sectorial de salud de Antioquia 1998-2000: Diagnóstico de salud. Medellín: Dirección Seccional de Salud de Antioquia; 1998. p.10-4.

4. Gaviria DL. Modelo de participación en enfermería en promoción de la salud y prevención de la enfermedad. Invest Educ Enferm. 2000; 18: 103-12.

5. Rozo C. Fundamentos pedagógicos que sustentan el proceso de la educación en salud. Aquichan. 2002; 2: 27-35.

6. Mendigure J, Huaman S, Ramos N, Valencia E. Efectividad de un programa de intervención educacional para la disminución de diarreas infantiles en Lima, Perú. Rev Cien Salud. [en línea]. 2007 [fecha de acceso: 14 de abril de 2010]; 2: 88-00. Disponible en: http://posgrado.upeu.edu.pe/revista/filev2/87100.pdf

7. Scoppeta O. Discusión sobre la evaluación de impacto en programas y proyectos sociales en salud pública. Univ Psychol. 2006; 5: 695-703.

8. Arrivillaga M, Salazar IC, Correa D. Creencias sobre la salud y su relación con las prácticas de riesgo o de protección en jóvenes universitarios. Colomb Med. 2003; 34: 186-95.

9. Choque R. Comunicación y educación para la promoción de salud. [Monografía en Internet]. Edición especial. Lima: $R a-$ zón y Palabra; 2005. [fecha de consulta: mayo de 2009]. Disponible en: http://www.razonypalabra.org.mx/libros/libros/ comyedusalud.pdf

10. Sousa V, Driessnack M, Costa IA. Revisión de diseños de investigación resaltantes para enfermería. Parte 1: Diseños de investigación cuantitativa. Latino-Am Enfermagem [en Línea]. 2007 Maio-Junho [fecha de acceso: 14 de abril de 2010]; 15: 1-6. Disponible en: http://www.scielo.br/pdf/rlae/v15n3/ es_v15n3a22.pdf

11. Cāballero R, Villaseñor A. Conocimientos sobre VIH/SIDA en adolescentes urbanos: consenso cultural de dudas e incertidumbres. Salud Publica Mex. 2003; 45 (Supl 1): 108-14.

12. Gutiérrez C, Villa S, Mota F, Cabrales RG, Gómez J. Intervención educativa para el manejo efectivo de diarrea en el hogar. Bol Med Hosp Infant Mex. 2004; 61: 19-28.

13. Ávila GA, Henne K, Posas J, Thurston A, Acosta ME, Withson D. Conocimientos y prácticas sobre nutrición infantil, enfermedades diarreicas y respiratorias en Lempira, Honduras. Rev Med Hond 2001. 2000; 69: 52-61.

14. Herrera G, Donet D, Triana I. Estrategia de capacitación para reducir las enfermedades diarreicas agudas en los menores de un año. MediCiego [en línea]. 2010 enero [fecha de acceso: 28 de abril de 2010]; 16: 1-9. Disponible en: http://bvs.sld.cu/ revistas/mciego/vol16_01_10/pdf/t5.pdf

15. Páez D, Ubillos S, Pizarro M, León M. Modelo de creencias de salud y de la acción razonada aplicados al caso del SIDA. Rev de Psicol Gral y Aplic. 1994; 47: 141-49.

16. Cabrera G, Tascón J, Lucumí D. Creencias en salud: historia, constructos y aportes del modelo. Rev Fac Nac Salud Publica. 2001; 19: 91-101. 